Agro-Science Journal of Tropical Agriculture, Food, Environment and Extension Volume 20 Number 3 (July 2021) pp. 1 - 8

ISSN 1119-7455

\title{
GROWTH OF SMALL AND MEDIUM-SIZED AGRICULTURAL ENTERPRISES AND EXPORT MARKET INTEGRATION BY SMALLHOLDER FARMERS
}

\author{
${ }^{* 1}$ Dagbelou V.K., ${ }^{2}$ Adekambi S.A. and ${ }^{3}$ Yabi J.A. \\ ${ }^{1}$ Institut Universitaire de Technologie-Université de Parakou - Benin (IUT/UP) \\ Centre de Recherche en Entrepreneuriat-Création et Innovation (CRECI) \\ Laboratoire de Recherche en Dynamique Economie et Sociale (LARDES - UP) \\ ${ }^{2}$ Institut Universitaire de Technologie-Université de Parakou - Benin (IUT/UP) \\ Centre de Recherche en Entrepreneuriat-Création et Innovation (CRECI) \\ Laboratoire de Recherche en Dynamique Economie et Sociale (LARDES - UP) \\ ${ }^{3}$ Département d'Economie et Sociologie Rurale (ESR), Faculté d'Agronomie, Université de Parakou, Bénin, \\ Laboratoire de Recherche en Dynamique Economie et Sociale (LARDES - UP) \\ *Corresponding author’s email: dagbeloud@gmail.com
}

\begin{abstract}
Small and medium-sized enterprise (SMEs) growth and survival constitute opportunities for the smallholders to become integrated into the export market. Smallholders can gain additional incomes from their transactions with SMEs and in turn, poverty problem could be alleviated. This article aims to better understand how export SMEs' growth and survival strengthens smallholders' market integration development and livelihood improvement. We collected data from 52 SMEs involved in the cassava and shea butter sectors in Benin. Interviews were organized, based on the need of value market access, with cassava producers in the Center Region, and women collecting and transforming shea nuts into butter in the Center and Northern Regions. When developing the measurement instrument, its validity and trustworthiness are concerned. SPSS was used for descriptive statistics and $R$ was used for Multiple Correspondence Factor Analysis. Results suggest that 96\% of SMEs exporting firms perceived exporting as profitable and resources generation tool. 95\% of smallholders appreciate SMEs as value added markets for their products. SMEs are institutional context for smallholders exchange experience in value added process, customers' needs and expectations satisfaction. They earn more profits from their selling when export SMEs grow and survive. Growth and survival are explained by export selling, share of exporting in total selling, satisfaction of Teklehaimanot exporting, manager perception of success and profitability and export profit.
\end{abstract}

Key words: SME's growth and survival, exporting, smallholders, market integration, livelihood

\section{INTRODUCTION}

The majority of smallholder agricultural producers in developing countries live and work in rural areas that are often quite remote from markets because of lack of infrastructure (Collier and Gunning, 1999). Although they operate in rural areas, they play important role by providing international trade with important industry raw materials such as coffee, tea and cocoa (Winter-Nelson and Temu, 2005; Buckley and Strange, 2015). Smallholder producers are also the main food suppliers for populations in developing countries. For example, Teklehaimanot et al. (2017) argued that African smallholder producers are providers of up to $70 \%$ of food in Africa. They collectively make important contribution to food security and rural development (Poulton et al., 2010). Moreover, sub-Saharan African smallholder producers serve local, regional and export markets (Shiferaw et al., 2011). They supply raw materials to agro-allied industries, represent a low-cost workforce of populations with low incomes, and often maintain informal trade networks (Teklehaimanot et al., 2017).

While there is a consensus that smallholder producers play important role in the production system (Teklehaimanot et al., 2017), they face many socio-economic and cultural constraints and have to cope with uncertainties such as climate change, market variation, soil degradation, political and social unrest. In addition, they also face problems in accessing markets (Adekambi et al., 2015). Hagos and Geta (2016) and Laube et al. (2017) identified that the major determinants of smallholder producers' commercialization level were in general population growth and geographic change, costs of transactions, assets holding of the

Please cite as: Dagbelou V.K., Adekambi S.A. and Yabi J.A. (2021). Growth of small and medium-sized agricultural enterprises and export market integration by smallholder farmers. Agro-Science, 20 (3), 1-8. DOI: https://dx.doi.org/10.4314/as.v20i3.1 
households and policy aspects such as technologies, institutions, risks, and markets. At the same time, Osmani and Hossain (2015), in their study conducted in Bangladesh, concluded that the good market infrastructure, provision of marketing incentives to smallholder producers and development of an institutionalized marketing information service are the key tools to enhance agricultural commercialization. Adekambi et al. (2015) identified information generation and dissemination by formal-sector organizations as key steps for smallholder producers to access rewarded markets such as export markets. Moreover, Teklehaimanot et al. (2017) concluded that smallholder farmers need specialized training on wants and expectations of customers, and on how to respect valued procurement by these customers to improve their access to rewarded markets. As they were low-resourced farmers, they could not solve all these problems themselves. However, the role played by SMEs in such integration of smallholders with rewarded markets remained unclear and needs further investigation.

The SMEs played a crucial role in economic development of developed as well as developing countries including Benin since they provide nations with employment, new products (Sarapaivanich, 2003; Saleh and Ndubisi, 2006; Muller et al. 2014) and can provide smallholders with access to sustainable markets with higher profitability. The SMEs seem to be as structured as possible to constitute market opportunities for producers. Since they live in the same institutional environment as smallholder producers, SMEs serving as exporters can stand as the potential and reliable intermediaries between smallholder producers and (large) firms in developed countries (Adekambi et al., 2015). The SMEs with moderately holdings and critical production factors, such as capital, information, and (basic) infrastructure such as storage facilities, can communicate efficiently the buying and selling standards to smallholder producers on behalf of (large) firms and provide them with the necessary incentives needed to comply with the quality and quantity requirements.

This paper offered such analysis on the role of SMEs in the integration of smallholder producers with export markets. The main research question addressed in this paper was: does SMEs' growth constitute market opportunities for the smallholder producers? Specifically, the present paper aimed to better understand how export SMEs' growth and survival strengthened smallholder producers' market development and livelihood improvement. The specific objectives of the study were to: (i) analyze export SMEs' growth and survival; (ii) examine smallholder producers' engagement to supply export SMEs; and (iii) apprehend the influence of SMEs' growth and survival on smallholder producers' livelihood.

\section{MATERIALS AND METHODS \\ Context and Study Area}

After governmental enterprises bankruptcy during the 1980's decade, most of the firms moved from public to private sectors. Private sector is composed of microenterprises, small, medium and large firms. Microenterprises worked in the primary sector, the agricultural sector, which is essentially individual and informal dependent sector. They are supported in their activities by the social network for their survival (Viswanathan, et al., 2010). It is generally argued that large firms are often successful because they have guarantees to borrow credit, have qualified employees and access to information about technologies and markets which smallholders cannot access. While large enterprises and microenterprises have the means to overcome their obstacles and objectives, small businesses are fighting for their existence (Viswanathan, et al., 2010).

The SME exporters are supplied with (agricultural) raw materials by smallholder producers (Adekambi et al., 2015). Agriculture is an important sector in Benin because of the number of active people employed and its contribution to export. Approximately $70 \%$ of the active populations gain their revenue from it. Agriculture contributes to $80 \%$ of exports' incomes and $15 \%$ of the gross domestic product (GDP) (INSAE, 2016; FAO et Commission de la CEDEAO, 2018). Recently agriculture participates with around 25 to $34 \%$ for GDP (Kate et al., 2017). Therefore, SMEs growth and survival can be opportunities to improve the integration of smallholder producers with markets.

\section{Who is the Smallholder Producer?}

There are several definitions of smallholder producers, depending on the author. For example, Dixon et al. (2003) defined smallholder as a producer with limited resource endowments as compared to other farmers in the sector. According to FAO (2012), smallholder producer refers, when limited to the agricultural sector, small-scale farmers, forest keepers, fishers or pastoralists that either use commonly owned natural resources or manage private lands of $<10$ hectares. The scopes and importance of smallholder producers in economy of developing countries are expanding. For example, 80, 75 and $90 \%$ of food in Nigeria, Kenya and Benin, respectively, are produced by smallholder farmers (UNDP, 2012). In Burundi, $71 \%$ of the tea, which is the second largest cash crop, is from smallholder producers (World Bank, 2008).

\section{SMEs' Importance in National Economy}

The SMEs contribution to the real Gross Domestic Product (GDP) growth, new job creation and poverty reduction is recognized at the worldwide level (Eze et al., 2010; Katua, 2014; Muller et al. 2014). For Katua (2014), the role of SMEs in economic 
development and employment creation has occupied most of discussion among government, policy makers, academicians-researchers-scholars and economists in Kenya and other countries. Kongolo (2010) supported this idea when he wrote that SMEs can fuel economic growth since they create new job, increase the tax base, and are generally drivers of innovation. According to Garikai (2011), SMEs are defined by number of workers employed, capital employed and sales turnover. SMEs are thus classified by the number of employees and/or the value of their assets. Micro, small and mediumsized enterprises are socially and economically important, since they represent $99 \%$ of all enterprises in the EU. They provide around 90 million jobs and contribute to entrepreneurship and innovation (Altun, 2017). The SMEs in Africa contribute more than $50 \%$ of most GDP and average of $60 \%$ of employment (Muriithi, 2017).

\section{SMEs' Growth and Survival}

The SMEs' growth and survival depend on export performance. The importance of SMEs' export performance analysis has gained more popularity in the literature. The concept of performance is a multifaceted and a complex phenomenon that is driven by various factors. The SMEs' export performance is argued to be indispensable in improving their downstream partners' (i.e. smallholder producers) access to export markets (Altun, 2017; Sousa et al., 2008). Cavusgil and Zou (1994) identified in their review that export performance was determined by marketing strategies, management and organization skills, and government assistance. They explain these results by the role of strategic marketing tools in satisfying international marketing needs through product quality, managers' competencies and government assistance to SMEs. Zou and Stan (1998) confirmed that performance consists of growth, profit, sales, satisfaction, success, goal achievement and composite scales.

Growth is the product of an internal process in the development of an enterprise and an increase in quality and or expansion. Growth is defined as a variation in size during a specified time frame (Dobbs and Hamilton, 2007). According to Machado and Machado (2016), a company's growth is essentially the result of increase in demands for its products or services. SMEs' growth results first in a growth in sales, which in turn will lead to increase in investments, in additional production factors and in interesting contract arrangements for smallholder producers to adapt themselves to new demands.

It has been argued that the key to SMEs' growth lay in the integration into their export value chains and the provision of supports to smallholder producers and their associations to improve product quality and delivery service. Local firms such as SMEs not only stand as sub- contractors for multinational firms, but also they could finally replace multinational firms through the transfer of technology and knowledge and management and market skills from these latter (Abodohoui et al., 2018).

\section{Data Collection}

To better understand how export SME's growth and survival strengthen smallholder producers' market development and livelihood improvement, the study utilized both secondary and primary data. Secondary data are from literature review and primary data from a survey. It focused on the agricultural sector because of not only its contribution to the country's economy growth but also it represents a main income source of smallholder producers (World Bank, 2009). We selected the cassava and shea nut sectors because they were the two products exporting SMEs procured as raw material from smallholder producers directly.

The collection of primary data took place in Central and Northern Regions of Benin. For the SMEs, they were geographically established, some in South, others in the Central and North Regions.

\section{Literature Review Process}

The literature analysis for this study consisted, first of all, of an analysis of the already existing unpublished documents and presentations at conferences on SMEs. Secondly, experiences from projects and programs on the integration of smallholder producers with (export) markets were incorporated, as well as a review of relevant scientific literature. We included important publications in the fields of export and SMEs' internationalization. For SMEs, we searched articles in google scholar in relation to: Journal of Marketing; International Marketing Review; Journal of International Marketing; Journal of the Academy of Marketing Science; Journal of International Business Studies; Management International Review; Journal of World Business; European Journal of Marketing and Industrial Marketing Management; Marketing Research and Applications, from 1970 to 2019.

As for smallholder producers' literature, we referred to development journals as follow: Journal of Public Policy and Marketing; Journal of Development and Agricultural Economics; Development and Change; Food Policy; International Food Policy Research Institute (IFPRI); Journal of Development Economics; Journal of Economic Perspectives; The European Journal of Development Research; International Review of Development Studies; Asian Journal of Economics and Empirical Research; International Association of Agricultural Economists; World Development; International Journal of Agricultural Resources, Governance and Ecology. 


\section{Survey Method}

In this study, 52 SMEs are identified as having commercial trading relation directly with smallholder producers. These SMEs are involved in shea nut and cassava processing. As we are studying smallholder producers' market integration these firms are retained in our study. Two SMEs are processing cassava to obtain alcohol when the 50 others are in shea nut transformation into shea butter. We collected data from 52 SMEs involved in cassava and shea butter added value products exporting from Benin. Interviews were organized, based on the need of rewarded market access, with cassava producers in the Center Region, and women teams working in shea nut collection and processing in Center and Northern Region. Questionnaire was used to collect the primary data. These data, among others, were on SMEs' export sales, share of exports in total sales, profit due to the SMEs, share of their procurements from smallholder producers, and characteristics of SMEs. Other data collected were related to SMEs' marketing plan, price competitiveness, exporting difficulties, raw material access difficulties, and existence of professional worker in the SMEs.

We used Snowball method to identify smallholder producers. We asked each of the SMEs to provide us with the names of some of smallholder producers that supply them with raw materials. Once we identified any of these smallholder producers supplying raw materials to SMEs, we asked them to bring us to other smallholder producers supplying to the SMEs. Six smallholder producers were interviewed per SMEs, leading to the total of 312 smallholder producers interviewed.

\begin{abstract}
Data Analysis
Descriptive statistics and Multiple Correspondence Factorial Analysis (MCFA) were used to analyze data. Descriptive statistics concerned SMEs' export characteristics such as: export sales, sales growth, export profitability, satisfaction of export selling, export profitability and export market share. Moreover, MCFA was used to test SMEs growth and survival and to know more about the subgroups of exporting SMEs which have possibility to strengthen smallholders' livelihood.
\end{abstract}

\section{RESULTS}

The presentation of the results was split into two parts, one of which presented exporting firms' characteristics analyzed by means of descriptive statistics whereas the other showed the typology of SMEs generated by means of the MCFA.

Descriptive Analysis: Categories of Sales, Export Intensity and Export Market Share The majority of the interviewed SMEs had total sales between 5 to 10 million FCFA per year (nearly $72 \%$ ), nearly $17 \%$ of them earned less than
5 million (Table 1). Only few of the interviewed SMEs brought in more than 10 million a year. In terms of export intensity, measured by the average percentage of export sales out of total sales, the majority of the interviewed SMEs (i.e., 89.80\%) are export focused. In fact, nearly $76 \%$ of the interviewed SMEs had their exports that accounted for between 25 to $50 \%$ of their total sales whereas nearly $14 \%$ had their exports accounting for in excess of $50 \%$ of the total sales.

The distribution of the exports across the SMEs' sales showed that the higher the sales the higher the export intensity. About $87 \%$ of the interviewed SMEs that had their exports that accounted for between 25 to $50 \%$ of their total sales had sales between 5 to 10 million FCFA annually. Nearly $57 \%$ of the SMEs that had their exports that accounted for in excess of $50 \%$ of the total sales had more than 10 million of sales annually. These results indicate that the larger the sales the higher the export intensity.

Almost all the interviewed SMEs reported that exporting activities were profitable. The majority of the respondents (ca 64\%) reported holding between 5 and $10 \%$ of the export market share in their exporting domain against only $1.89 \%$ that reported holding between 10 and $25 \%$ of their market share.

Categories of Small and Medium-Sized Enterprises The categories of SMEs were assessed by means of MCFA. The MCFA analysis led to four groups of SMEs (Figure 1). The horizontal axis represented the marketing plan and the vertical axis the competitiveness level. On the vertical axis, at the highest level, the first group (cluster 2) was composed of the SMEs competitive on export markets. These SMEs have contracts with suppliers, i.e., smallholder producers, and maintain good relations with customers in foreign markets. On the appositive, i.e., at the lowest level of the vertical axis, the second group (cluster 3) was composed of the SMEs with low competitiveness. They sourced their raw materials directly from (rural) markets and do not have any contracts with smallholder producers. Since SMEs in this group were less competitive on foreign markets, they had their exports that accounted for $<5 \%$ of their total sales annually, with relatively less foreign customers.

Table 1: Descriptive statistics

\begin{tabular}{lcc}
\hline & \multicolumn{2}{c}{$\%$ of SMEs } \\
\hline Sales & $<5$ million & 16.98 \\
& $5-10$ million & 71.70 \\
& $>10$ million & 11.32 \\
Proportion of export & $<25 \%$ & 10.20 \\
sales out of the total sales & $25-50 \%$ & 75.51 \\
& $>50 \%$ & 14.29 \\
Being export & Slightly profitable & 1.92 \\
focused profitability & Profitable & 76.92 \\
& Very profitable & 21.16 \\
Export market share & $<5 \%$ & 33.96 \\
& $5-10 \%$ & 64.15 \\
& $10-25 \%$ & 1.89 \\
\hline
\end{tabular}




\section{Factor map}



Figure 1: SMEs clusters

The other two groups were with an average competitiveness level. On the right side of the horizontal axis, the third group (cluster 4) was composed of the SMEs that had functional marketing plan with qualified employees. These SMEs were characterized by product delivery on time. The last group of SMEs (cluster 1), on the left side of the horizontal axis, employed less qualified employees and as such were not able to manage export plan properly. As consequence, they faced difficulties in supplying their foreign customers on time.

The results showed that two groups, the SMEs with high competitiveness and those with functional marketing plan with qualified employees, play an important role in the integration of smallholder producers into export market.
Impact of SME's Growth and Survival on Smallholder Producers' Export Market Integration

To assess the impact of SME's growth and survival on smallholder producers' export market integration, we relied on the proportion of the raw materials that the SMEs bought from smallholder producers. Table 2 shows that the more competitive in the export market is the SME (and or the more functioning its marketing plan), the higher the proportion of its raw materials sourced from smallholder producers, and thereby the greater will be smallholder producers' export market integration. The SMEs with competitive competencies on export markets (cluster 2) showed a higher proportion of their raw materials coming from smallholder producers (71\% in 2017 and $75 \%$ in 2018). The SMEs with functional marketing plans also bought a relatively higher proportion of their raw materials (62\% in 2017 and $64 \%$ in 2018) from smallholder producers. In 2018, SMEs in cluster 2 bought about $75 \%$ of their raw materials from smallholder producers (64\% for SMEs in cluster 4$)$ as compared to $21 \%$ for SMEs in cluster 1 (SMEs with nonfunctional marketing plans and unqualified employees) and $28 \%$ for those in cluster 3 (uncompetitive SMEs in export markets).

Therefore, the trends of the sales to export markets showed that smallholder producers selling to SMEs with competitive competencies and/or those with functional marketing plans outperformed their counterparts.

Besides, the proportions of smallholder producers provided with contract terms were analyzed. It was observed that SMEs with competitive competencies and/or functional marketing plans are those providing smallholder producers with adequate contract options. For example, in 2018, the SMEs in cluster 2 bought $47 \%$ of the total raw materials from smallholder producers ( $8 \%$ for SMEs in cluster 4 ) via contract agreements as compared to $0 \%$ for SMEs in clusters 1 and 3. Contracts in supply chains have potential to reduce transaction costs and solve market imperfections (Swinnen and Maertens, 2007; Oya, 2012). According to smallholder producers, selling to SMEs through contracts not only helped them join benefit from several trainings on quality improvement specific services (access to inputs, credit, and technology, and technical field assistance) but also offered a guaranteed rewarded markets such as export markets.

Table 2: Clusters of raw material proportion and raw material by contract

\begin{tabular}{lcc|cc}
\hline Clusters of SMEs & \multicolumn{2}{c|}{$\begin{array}{c}\text { Proportion of raw materials from } \\
\text { smallholder producers }\end{array}$} & $\begin{array}{c}\text { Proportion of raw materials from } \\
\text { smallholder producers with contract }\end{array}$ \\
\hline & 2017 & 2018 & 2017 & 2018 \\
Cluster 1 & 19 & 21 & 0 & 0 \\
Cluster 2 & 71 & 75 & 45 & 0 \\
Cluster 3 & 28 & 0 & 8 \\
Cluster 4 & 62 & 64 & 7 & 8 \\
\hline
\end{tabular}




\section{Impact of SME's Growth and Survival on Smallholders' Incomes}

Table 3 displays the income differences by SMEs categories. In terms of income growth, smallholder producers who sold to SMEs with competitive competencies on export markets (cluster 2) and / or SMEs with functional marketing plans and qualified employees (cluster 4) outperformed their counterparts. A comparison test was also performed if there is any difference in the incomes according to SMEs clusters. The test results indicated that smallholder producers who sold to SMEs with competitive competencies on export markets (cluster 2) obtained the greatest increase in income, followed by those who sold to SMEs with functional marketing plans and qualified employees (cluster 4), and earning the lowest incomes were those selling to SMEs belonging to clusters 3 (SMEs with low competencies on export markets) and 1 (SMEs with less qualified employees and unable to manage export plan properly. These results imply that SME's growth and survival are positively and significantly associated with smallholder producers' income.

\section{DISCUSSION}

The effort on the inclusion of smallholder producers into export chains is relevant in the improvement of their livelihood status and in the reduction of poverty in general. The majority of smallholder producers are often quite isolated from markets because of lack of adequate infrastructure. Hence, the effectiveness of initiatives to promote export market integration via SMEs, as potential and reliable intermediaries between smallholder producers and (large) firms in developed countries, will ultimately depend on how competitive the SMEs are. The analysis of responses from 52 Beninese SMEs with which smallholder producers interact revealed four types of SMEs: SMEs with competitive competencies on export markets, SMEs with functional marketing plan and qualified employees, SMEs with low competencies on export markets, and those with less qualified employees and unable to manage export plan properly.

From these findings, it can be deduced that understanding with which SMEs smallholder producers should be interacted was imperative for the ultimate integration with export markets. The present article provided empirical evidence about the intermediating role played by SMEs in the process of integration of smallholder producers with export markets. Those SMEs with core competitive competencies as well as functional marketing plans, have been found to constitute significant and reliable intermediaries in integrating smallholder producers with export markets. They have been found to contribute to the promotion of smallholder producers' export market integration, since the more competitive in the export market is the SME
Table 3: Producer's incomes by SMEs cluster

\begin{tabular}{lcccc}
\hline & \multicolumn{2}{c}{ Income $(1,000$ FCFA) } & \multicolumn{2}{c}{ Proportions (\%) } \\
& 2017 & 2018 & 2017 & 2018 \\
\hline Cluster 1 & $110^{\mathrm{a}}$ & $115^{\mathrm{a}}$ & $19^{\mathrm{a}}$ & $21^{\mathrm{a}}$ \\
Cluster 2 & $450^{\mathrm{b}}$ & $465^{\mathrm{b}}$ & $71^{\mathrm{b}}$ & $75^{\mathrm{b}}$ \\
Cluster 3 & $140^{\mathrm{a}}$ & $145^{\mathrm{a}}$ & $27^{\mathrm{c}}$ & $28^{\mathrm{c}}$ \\
Cluster 4 & $320^{\mathrm{c}}$ & $325^{\mathrm{c}}$ & $62^{\mathrm{d}}$ & $64^{\mathrm{d}}$ \\
\hline
\end{tabular}

FCFA - Franc of the Financial Community of Africa

Within the same column, the values with the same superscripts are not significantly different at the 0.1 level. The values with the different superscripts are significantly different at the 0.05 level.

(and or the more functioning its marketing plan), the greater is the export market integration level of smallholder producers. Consequently, as producers consider entering export market channels, they should research their (export) market intermediaries thoroughly; they need to identify those SMEs with competitive competencies on export markets and with functional marketing plan and qualified employees. These results agree with Katua (2014) that linking smallholder producers with SMEs is one of the important development interventions to make them access (export) markets.

The results revealed that there is a significant correlation between the types of SMEs with which the smallholder producer is in cooperation and the proportion of its produced sold via export chains. This provides empirical evidence about the central role played by SMEs in lowering the export transaction costs by intermediating between smallholder producers and customers in developed countries. Besides, it is considered that financial performance of smallholder producers will increase as SMEs expand and reinforce their competitive competencies and build up functional marketing plans. These results are similar to those reported by a number of past studies (e.g., Diao et al., 2018; Kweka and Sooi, 2020). For example, Kweka and Sooi (2020) reported that linkages with large firms have been found to be one of the significant important drivers of SMEs performance in Tanzania through improvement in market access. Diao et al. (2018) argued that SMEs play a key role in partners' productivity increase in developing countries.

Enhanced smallholder producers' access to export markets leads to greater income that permits smallholder producers to improve their livelihoods. Enhanced linkages with competitive SMEs contributed to increased export market participation through greater smallholder producers' knowledge of improved quality practices. Linkages with SMEs also contributed to reduced (export) transaction costs through bulk sales. These results are consistent with those of McKague and Oliver (2012) who argued that collective action, linkages of smallholder producers and SMEs in our case, had significant positive impact on farmer productivity. 
The major implication following from this study was that, if SMEs choose to play intermediating role between smallholder producers and endcustomers in developed countries, they need to develop their competitive competencies on export markets and put in place functional marketing plans. Beninese smallholder producers benefitted from an intermediary organization model that improved transactions between SMEs and smallholder producers. SMEs benefitted from greater reliability and quality of product delivery while smallholder producers benefitted from market growth and a stable market by SMEs. Smallholder producers also benefitted from training in quality improvement practices which provided them with knowledge and incentives to provide high-quality output, leading SMEs that obtain much higher quality inputs with reduced exposure to food safety liabilities. Our findings suggest that SMEs seeking to profitably improve smallholder producers' integration with export markets would be well advised to assess their own export competitiveness capabilities to implement functional marketing plans, i.e., marketenhancing practices, that can be mutually beneficial to both the SMEs and smallholder producers.

\section{CONCLUSION}

Strategic organization-level approaches to improve (export) market integration of smallholder producers in developing countries confront challenges to market linkages. While the literature identifies different categories of SMEs and reveals that linkages between smallholder producers and SMEs are in general beneficial, which types of linkages perform best for smallholder producers in developing countries remains empirical question. We sought new insights into the intermediating role of SMEs by investigating the types of linkages that delivered tangible export market integration benefits. We found that linking smallholder producers with SMEs requires a strategic SME-level approach that necessitates that SMEs implement higher competitive competence in export market as they participate. We argued that SMEs' ability to enhance competitive competencies in ways that can improve smallholder producers' (export) market participation. We found that linking smallholder producers to SMEs increases smallholder producers' participation in export chains and incomes but with implications for SMEs categories. The types of SMEs matter as shown by the difference in the level of export market integration and income across SMEs categories. Across different types of SMEs, linkages between smallholder producers and SMEs with competitive competencies in exporting and or with functional marketing plans led to greater export market integration and greater incomes. The implications of these findings are that category considerations should be integrated during the SMEs selection for linkages with smallholder producers.

\section{REFERENCES}

Abodohoui A., Su Z. and Da-Silva I. (2018). Chinese investments in Africa: What have we learnt? Manage. Int., 22 (3), 129-142. https://doi.org/10. 7202/1060899ar

Adekambi S., Ingenbleek P. and van Trijp H. (2015). Integrating producers at the base of the pyramid with global markets: A market learning approach. J. Int. Market., 23 (4), 44-63. https://doi.org/10.1509/jim .14 .0087

Altun I. (2017). Determinants of the export performance of SMEs: Comparative analysis of Turkish SMEs exporting to Middle East and European Regions. Int. J. Bus. Soc. Sci., 8, 75-83

Buckley P.J. and Strange R. (2015). The governance of the global factory: Location and control of world economic activity. Acad. Manag. Persp., 29 (2), 237-249. https://doi.org/10.5465/amp.2013.0113

Cavusgil S.T. and Zou S. (1994). Marketing strategyperformance relationship: An investigation of the empirical link in export market ventures. J. Marketing, 58 (1), 1-21. https://doi.org/10.2307/1252247

Collier P. and Gunning J.W. (1999). Why has Africa grown slowly? J. Econ. Persp., 13 (3), 3-22. https://doi.org/10.1257/jep.13.3.3

Diao X., Kweka J. and McMillan M. (2018). Small firms, structural change and labor productivity growth in Africa: Evidence from Tanzania. World Dev., 105, 400-415. https://doi.org/10.1016/j.worlddev.2017.12.016

Dixon R.M., Karda W., Hosking B.J. and Egan A.R. (2003). Effects of oilseed meals and grain-urea supplements fed infrequently on digestion in sheep: 2. Cereal straw diets. Anim. Feed Sci. Technol., 110 (1-4), 95-110

Dobbs M. and Hamilton R. (2007). Small business growth: Recent evidence and new directions. Int. J. Entrep. Behaviour Res., 13, 296-322. https://doi.org/ $10.1108 / 13552550710780885$

Eze S.O., Onwubuya E.A. and Ezeh A.N. (2010). Women marketers' perceived constraints on selected agricultural produce marketing in Enugu South Area: Challenges of extension training for women groups in Enugu State, Nigeria. Agro-Science, 9 (3), 215222. https://doi.org/10.4314/as.v9i3.65762

FAO (2012). Smallholders and family farmers. Food and Agriculture Organization. Accessed 30/05/2021 from http://www.fao.org/fileadmin/templates/nr/sustainabi lity_pathways/docs/Factsheet_SMALLHOLDERS.pdf

FAO et Commission de la CEDEAO (2018). Profil National genre des secteurs de l'agriculture et du développement rural au Bénin, 1- 152. Consulted on $26^{\text {th }}$ May, 2021. http://www.fao.org/publications/ card/en/c/I9671FR/

Garikai B.W. (2011). Exportation challenges by small and medium enterprises and possible exportation strategies. J. Finance, 95 (18), 105-126

Hagos A. and Jeta E. (2016). Review on small-holders agriculture commercialization in Ethiopia what are driving factors to focused. J. Dev. Agric. Econs., 8 (4), 65-76. DOI: 10.5897/JDAE2016.0718

INSAE (2016). Effectifs de la population des villages et quartiers de ville du Bénin (RGPH-4 2013) Primature, République du Bénin, UNICEF-UNFPA, p. 85

Kate S., Teka O., Chabi R.B., et al. (2017). Simulation $\mathrm{du}$ climat futur bet des redements agricoles en région Soudano-Sahelienne en République du Bénin. Afr. Crop Sci. J., 25, 405-417 
Katua N.T. (2014). The role of SMEs in employment creation and economic growth in selected countries, Int. J. Edu., Res., 2 (12), 461-472

Kongolo M. (2010). Job creation versus job shedding and the role of SMEs in economic development. Afr. $J$. Business Manage., 4 (11), 2288-2295

Kweka J.P. and Sooi F. (2020). Partnership for inclusive growth: Can linkages with large firms spur the growth of SMEs in Tanzania? https://www.africaportal. org/publications/partnership-inclusive-growth-canlinkages-large-firms-spur-growth-smes-tanzania/. Consulted on $30^{\text {th }}$ Nov., 2020

Laube W., Awo M. and Derbile E.K. (2017). Smallholder integration into the global shea nut commodity chain in Northern Ghana, (Working Paper Nº153). Consulté à l'adresse ZEF Working Paper Series website: https://www.econstor.eu/handle/10419/162194

Machado H.P. and Machado P. (2016). Crescimento de pequenasempresas: Revisão de literatura e perspectivasde estudos. Gest. Prod., 23 (2), 419-432. https://doi.org/10.1590/0104-530x1759-14

McKague K. and Oliver C. (2012). Enhanced market practices as redistribution of social control. California Manage. Rev., 55 (1), 98-129

Muller, P., Gagliardi, D., Caliandro, C., et al. (2014). A partial and fragile recovery - Annual Report on European SMEs 2013/2014. (SME Performance Review 2013/2014). European Commission, Directorate General for Enterprise and Industry, 1-125

Muriithi M.S. (2017). African small and medium enterprises (SME) contributions, challenges and solutions. Europ. J. Res. Ref. Manage. Sci., 5 (1), 36-48

Osmani M. and Hossain M. (2015). Market participation decision of smallholder farmers and its determinants in Bangladesh. Economics of Agriculture, 62, 163-179. https://doi.org/10.5937/ekoPolj1501163G

Oya C. (2012). Contract farming in Sub-Saharan Africa: A survey of approaches, debates and issues. J. Agr. Change, 12 (1), 1-33

Poulton C., Dorward A. and Kydd J. (2010). The future of small farms: New directions for services, institutions, and intermediation. World Dev., 38 (10), 1413-1428. https://doi.org/10.1016/j.worlddev.2009.06.009

Saleh A.S. and Ndubisi N.O. (2006). An evaluation of SME development in Malaysia. Int. Rev. Business Res. Papers, 2 (1), 1-14
Sarapaivanich N. (2003). The use of financial information in financial decisions of SMEs in Thailand. In: Annual Conference of Small Enterprise Association of Australia and New Zealand, 16, 1-28

Sousa C., Martínez-López F. and Coelho F. (2008). The determinants of export performance: A review of the research in the literature between 1998 and 2005. Int. J. Manag. Rev., 10. https://doi.org/10.1111/j.14682370.2008.00232.x

Swinnen J. and Maertens M. (2007). Globalization, privatization, and vertical coordination in food value chains in development and transition countries. Agric. Econ., 37, 89-102

Teklehaimanot M., Ingenbleek P. and Trijp H. (2017). The transformation of African smallholders into customer value creating businesses: A conceptual framework. J. Afr. Bus., 18 (3), 299-319. https://doi.org/10.1080/15228916.2017.1297628

UNDP (2012). Food production and consumption trends in sub-Saharan Africa: Prospects for the transformation of the agricultural sector (Working Paper, 4-29). Africa regional bureau: UNDP

Viswanathan M., Rosa J. and Ruth J. (2010). Exchanges in marketing systems: The case of subsistence consumer merchants in Chennai, India. J. Market., 73 (3), 1-17

Winter-Nelson A. and Temu A. (2005). Impacts of prices and transactions costs on input usage in a liberalizing economy: Evidence from Tanzanian coffee growers. Agric. Econ., 33 (3), 243-253. https://doi.org/10. 1111/j.1574-0864.2005.00064.x

World Bank (2008). Agriculture for Development. World Development Report. Washington, DC. Available at: https://openknowledge.worldbank.org/handle/10986/5990

World Bank (2009). Agriculture: an engine for growth and poverty reduction. IDA at work Washington, DC: World Bank Group. Accessed 24/06/2021 from: http://documents.worldbank.org/curated/en/2184814 68330879242/Agriculture-an-engine-for-growth-andpoverty-reduction

Zou S. and Stan S. (1998). The determinants of export performance: A review of the empirical literature between 1987 and 1997. Int. Market. Rev., 15 (5), 333-356. https://doi.org/10.1108/02651339810236290 